\title{
Conservation Agriculture Practices in Rainfed Uplands of India Improve Maize-Based System Productivity and Profitability
}

\author{
Aliza Pradhan ${ }^{1 *}$, Travis Idol ${ }^{1}$ and Pravat K. Roul ${ }^{2}$ \\ 1 Department of Natural Resources and Environmental Management, University of Hawaii at Manoa, Honolulu, HI, USA, \\ ${ }^{2}$ Directorate of Planning, Monitoring and Evaluation, Orissa University of Agriculture and Technology, Bhubaneswar, India
}

\section{OPEN ACCESS}

Edited by:

B. Mohan Kumar:

Nalanda University, India

Reviewed by:

Florian Wichern,

Rhine-Waal University of Applied

Sciences, Germany

Somasundaram Jayaraman,

Indian Council of Agricultural

Research - Indian Institute of Soil

Science, India

*Correspondence:

Aliza Pradhan

alizapradhan@gmail.com

Specialty section:

This article was submitted to Agroecology and Land Use Systems, a section of the journal

Frontiers in Plant Science

Received: 25 December 2015

Accepted: 27 June 2016

Published: 15 July 2016

Citation:

Pradhan A, Idol T and Roul PK (2016) Conservation Agriculture Practices in Rainfed Uplands of India Improve Maize-Based System

Productivity and Profitability.

Front. Plant Sci. 7:1008.

doi: 10.3389/fpls.2016.01008
Traditional agriculture in rainfed uplands of India has been experiencing low agricultural productivity as the lands suffer from poor soil fertility, susceptibility to water erosion and other external pressures of development and climate change. A shift toward more sustainable cropping systems such as conservation agriculture production systems (CAPSs) may help in maintaining soil quality as well as improving crop production and farmer's net economic benefit. This research assessed the effects over 3 years (20112014) of reduced tillage, intercropping, and cover cropping practices customized for maize-based production systems in upland areas of Odisha, India. The study focused on crop yield, system productivity and profitability through maize equivalent yield and dominance analysis. Results showed that maize grain yield did not differ significantly over time or among CAPS treatments while cowpea yield was considered as an additional yield in intercropping systems. Mustard and horsegram grown in plots after maize cowpea intercropping recorded higher grain yields of 25 and 37\%, respectively, as compared to those without intercropping. Overall, the full CAPS implementation, i.e., minimum tillage, maize-cowpea intercropping and mustard residue retention had significantly higher system productivity and net benefits than traditional farmer practices, i.e., conventional tillage, sole maize cropping, and no mustard residue retention. The dominance analysis demonstrated increasing benefits of combining conservation practices that exceeded thresholds for farmer adoption. Given the use of familiar crops and technologies and the magnitude of yield and income improvements, these types of CAPS should be acceptable and attractive for smallholder farmers in the area. This in turn should support a move toward sustainable intensification of crop production to meet future household income and nutritional needs.

Keywords: rainfed uplands, system productivity, maize equivalent yield, dominance analysis

\section{INTRODUCTION}

Traditional, rainfed agro-ecosystems are still important in India, contributing up to $44 \%$ of the country's annual food production. In Odisha, India, one of the poorest states in the country, maize-based cropping systems are common in the interior districts, which are dominated by tribal communities (Pradhan et al., 2015). A common cropping system is maize (Zea mays L.) followed by mustard (Brassica juncea L.) and then a fallow period during the dry season. 
During the onset of the monsoonal rainy season, seeds of openpollinated and low-yielding varieties of maize are broadcast sown into fields prepared by multiple plowings with a simple bullockdrawn plow that cuts into the soil but does not turn it over like a moldboard plow. Uncomposted farmyard manure and low levels of urea $\left(\sim 10 \mathrm{~kg} \mathrm{ha}^{-1}\right)$ are typically the only soil amendments provided for the crops. After harvest, if residual soil moisture is sufficient, farmers will plow the field again and broadcast sow seeds of local varieties of mustard.

While maize stover is typically left in fields after harvest, it is not deliberately utilized for mulch or soil cover. Plowing for mustard tends to incorporate most of the residue, leaving little soil cover. For mustard, the entire aboveground stem is harvested and the seeds removed by threshing for extraction of oil. Residues from threshing are typically piled and burned as waste. During the dry season that follows mustard harvesting, livestock are generally allowed to freely graze crop fields, eating any remaining live or dead plant material.

This combination of using traditional crop varieties, multiple plowings, repeated maize cultivation, no attempt at soil cover, and low inputs has resulted in low yields and thus low food security and income for farmers in these districts. One approach to addressing these issues is the introduction and adaptation of conservation agriculture production systems (CAPSs). CAPS are defined as integrated production systems consisting of minimum soil disturbance, appropriate crop rotation or intercropping, and continuous organic soil cover (Roul et al., 2015). The integrated nature of CAPS builds on decades of research in more large-scale and mechanized farming systems in which zero- or minimum-tillage systems were developed and combined with crop rotation and residue retention or cover cropping to reduce soil erosion and related declines in soil and natural resource quality (Idol, 2015). Only more recently have these concepts been adapted and applied to smallholder cropping systems, where conventional Green Revolution approaches to improving crop yield (better seed, higher input rates, mechanization) are unfeasible or have been unsustainable (Giller et al., 2009; Gilbert, 2012).

Given the obvious variability of agro-ecological environments, cropping systems, and farmer capacities and preferences, there is not a single CAPS that applies worldwide. Therefore, successful introduction of CAPS depends upon adapting and tailoring the basic principles to the local context. As maize is the staple crop in tribal areas of Odisha, a maize-based CAPS is needed to improve agronomic, environmental, and socioeconomic sustainability in these areas. Therefore, the objective of this study was to investigate the effects of maize-based CAPS on crop yield, system productivity, and profitability in a rainfed low-input region of Odisha, India.

\section{MATERIALS AND METHODS}

\section{Experimental Site}

A field experiment was conducted in rainfed uplands at the Regional Research and Technology Transfer Station (RRTTS; $85^{\circ}$ $34^{\prime} 30.61^{\prime \prime} \mathrm{E}, 20^{\circ} 50^{\prime} 55.38^{\prime \prime} \mathrm{N}$; $499 \mathrm{~m}$ above mean sea level) of
Orissa University of Agriculture and Technology (OUAT) in the Keonjhar district, Odisha, India over three cropping cycles, from 2011 to 2014 . The soil of the study site is mainly developed from colluvial-alluvial deposits in piedmont plain with soil texture ranging from sandy clay loam to sandy loam with $\mathrm{pH}(6.5)$ and classified as Fluventic Haplustepts (Inceptisol). The basic soil characteristics of the experimental site for $(0-20) \mathrm{cm}$ soil depth, measured just before laying out the field in 2011-12 were; total carbon $1.86 \%$, total nitrogen $(\mathrm{N}) 0.2 \%$, available phosphorous

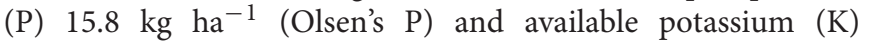
$341.8 \mathrm{~kg} \mathrm{ha}^{-1}$ (ammonium acetate flame photometry method). The climate of the study area is sub-humid tropical with average annual rainfall of $1500 \mathrm{~mm}$, with more than $75 \%$ of the rainfall received in the months from May to September (Figure 1). The usual cropping system of the study site is maize during the rainy season (mid June-September) followed by mustard (Brassica campestris L.) as a post-rainy season crop (OctoberJanuary).

\section{Selection of CAPS Treatments}

A set of CAPSs practices were selected based on discussions with farmers, researchers, and extension personnel regarding their tillage and crop preference, past cropping history of the area, market demand, other threats and challenges (Lai et al., 2012). In order to reduce soil erosion, a minimum tillage method of plowing once before planting was proposed as an alternative to the conventional practice of plowing three times. Again, because of the central importance of maize as a staple food and the limitation of land for rotation, an intercropping rather than crop rotation option was selected. Cowpea (Vigna unguiculata L.) was considered suitable as an intercrop as it is a legume and will help in biological nitrogen fixation; has a high market value (twice that of maize); and local farmers have had some previous experience with growing and selling it. In order to address the cover crop and residue management principle, horse gram (Macrotyloma uniflorum) was selected as an alternative post-rainy season monocrop in addition to mustard. Horse gram was the preferred cover crop option as it provides economic yield as well as acts as a legume soil cover. Both horse gram and mustard grow reasonably well on residual soil moisture and mature better with dry weather during the late vegetative and reproductive stages (i.e., during January).

\section{Experimental Design and Layout}

The experiment was initiated in May 2011. The experimental design was a randomized complete block, split-plot design with three replicates, one per block (Figure 2). Each plot dimension was $10.2 \mathrm{~m}$ in length $\times 7.2 \mathrm{~m}$ in width. Tillage and cropping system were the main plot treatments, and cover crop selection was the split-plot treatment. The main plot treatments compared four management practices: conventional tillage with maize cropping (CT-M); conventional tillage with maize+cowpea (1:1; Vigna unguiculata L.; CT-M+C); minimum tillage with maize cropping (MT-M); and minimum tillage with maize+cowpea $(1: 1$; MT-M+C). Conventional tillage consisted of plowing the field with a bullock-drawn plow. A single 


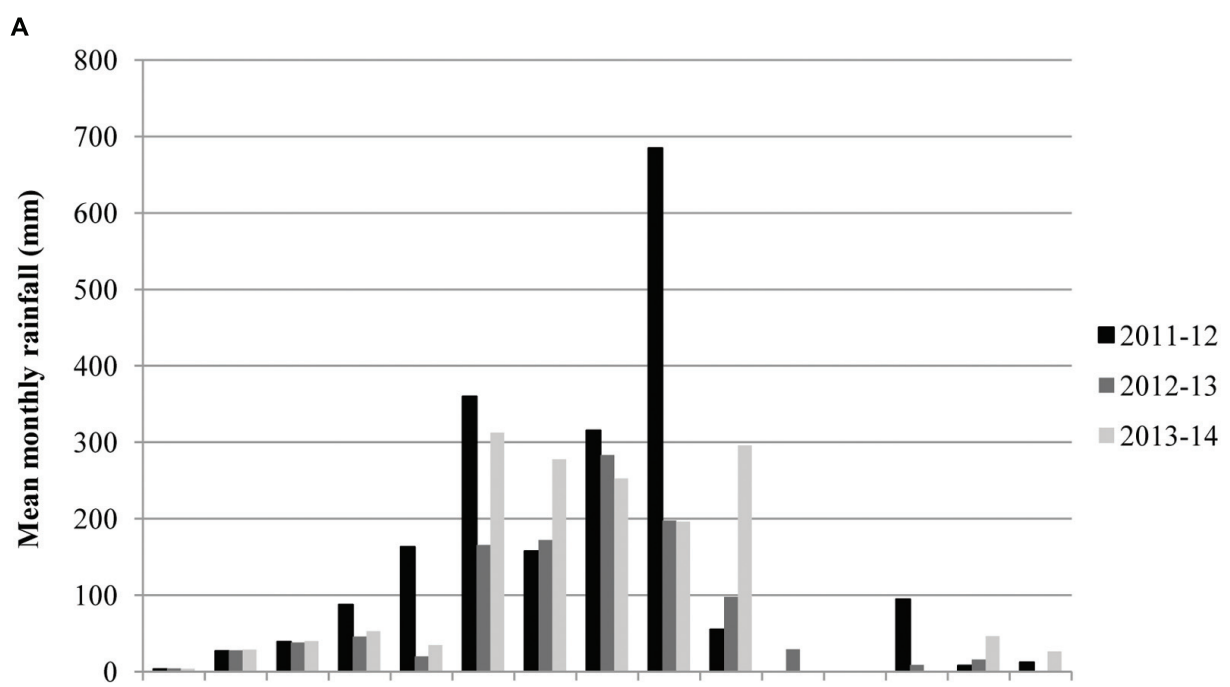

Jan Feb Mar Apr May Jun Jul Aug Sep Oct Nov Dec Jan Feb Mar

B

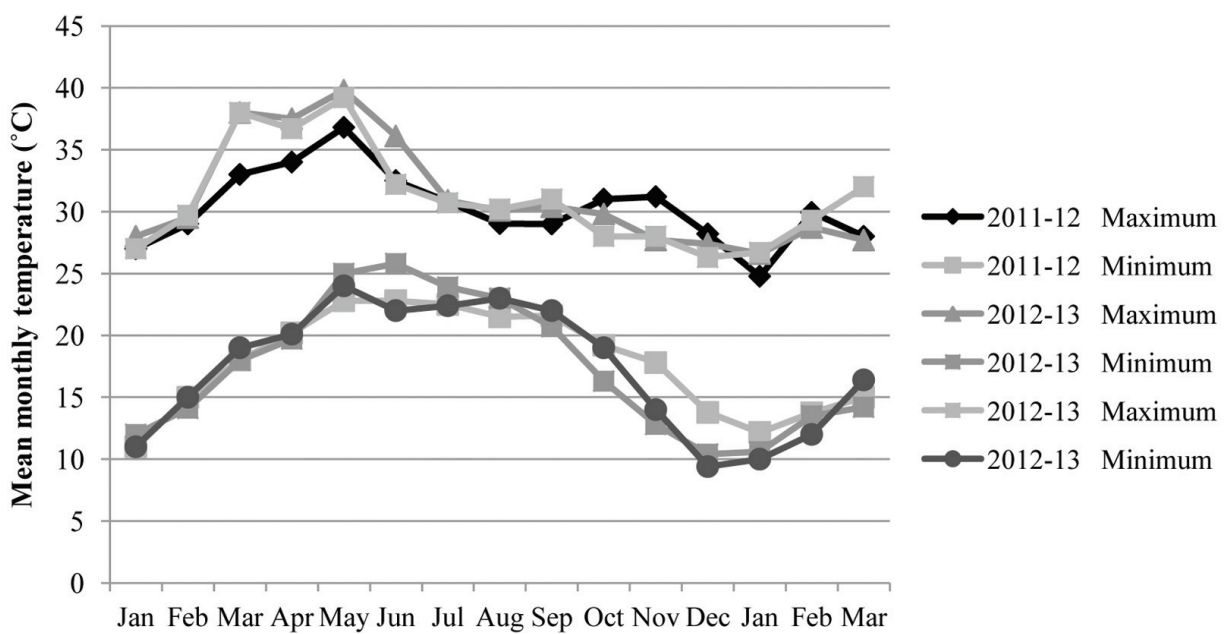

FIGURE 1 | Mean monthly rainfall (A) and mean monthly maximum and minimum temperature (B) during cropping periods of 2011-12, 2012-13, and 2013-14.

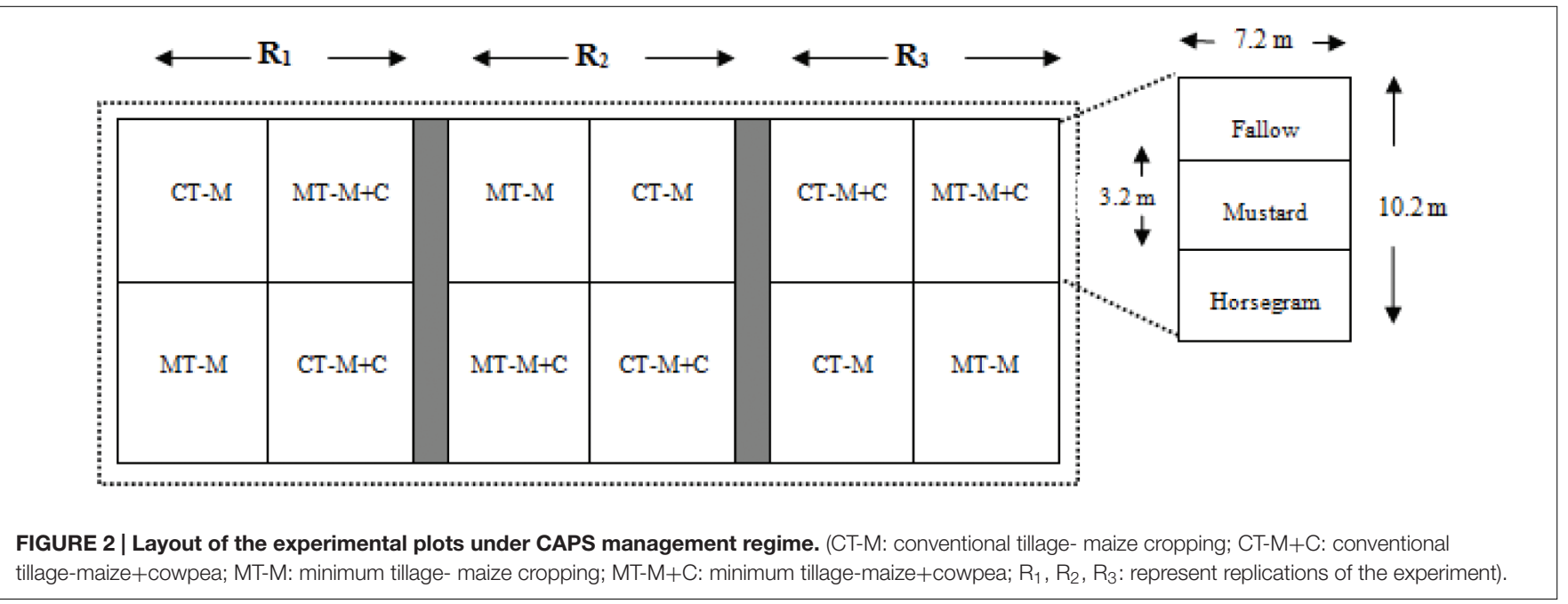


pass of the plow was done during the pre-monsoonal rains, a few days to weeks prior to the expected heavy monsoonal rains. After the onset of monsoonal rains, the field was crisscross plowed. Though farmers' normal practice is to broadcast maize seed throughout the plot, this study used line sowing of maize seed to maintain consistency with the minimum tillage treatment. Minimum tillage consisted of a single plowing prior to sowing followed by strip-tilling rows with hand-held hoes to sow maize seed. Hand-weeding with hoes occurred several times afterward in both the tillage systems. No novel tools or equipment often used with conservation agriculture, e.g., seed drills or chisel plows, were used due to lack of local availability and farmer experience with them. After harvest of maize and cowpea, the plot was prepared for planting of cover crops. Each plot was split into thirds and randomly assigned to one of three cover crop treatments: no cover crop, i.e., fallow (F), mustard (Brassica campestris L.) as cover crop (Mu), and horse gram (Macrotyloma uniflorum)as cover $\operatorname{crop}(\mathrm{H})$.

\section{Selection of Crop Varieties and Calendar of Agricultural Operations}

The crop varieties and spacing used in the study are shown in Table 1. Maize was harvested manually approximately 90 days after sowing. Because cowpea is an indeterminately flowering and fruiting crop, manual harvesting of mature seed pods began approximately 40 days after sowing and continued until 60 days.

After final harvest of both maize and cowpea, crop residues were left as such in the fields, and the plot was prepared by strip-tilling rows with hand held hoes for planting of cover crops (Figure 2). The cover crops were harvested approximately 75 days after sowing. After threshing, all residues were collected on plastic tarpaulins and returned back to their respective plots.

\section{Crop Harvest and Yield Estimation}

Yield measurements of maize, mustard, and horsegram grains were done after harvesting and threshing the crops at crop maturity. Grain yield of these crops are reported at $12 \%$ grain moisture content. Cowpea green pods were picked manually at 7-days intervals, and their fresh weight after each harvest was recorded. Grain and stover yields of the crops were determined by harvesting three areas in a $1 \mathrm{~m} \times 1 \mathrm{~m}$ grid cell within each plot. To estimate the effect of CAPS on total system productivity, yields of all non-maize crops were converted to maize equivalent yield (MEY) based on market prices using Eq. (1). The market

TABLE 1 | Details of the crop varieties, spacing $(\mathrm{cm})$ and plant population (plants ha-1).

\begin{tabular}{lccc}
\hline Crop & $\begin{array}{c}\text { Selected } \\
\text { variety }\end{array}$ & $\begin{array}{c}\text { Spacing } \\
\text { (cm) }\end{array}$ & $\begin{array}{c}\text { Plant } \\
\text { population } \\
\text { (plants ha } \mathbf{~ h}^{\mathbf{1}} \text { ) }\end{array}$ \\
\hline Maize & Nilesh & $60 \times 30$ & 55,555 \\
Cowpea & Hariyalli Bush & $30 \times 15$ & 222,222 \\
Mustard & Parvati & $30 \times 10$ & 333,333 \\
Horsegram & Athagada Local & $30 \times 10$ & 333,333
\end{tabular}

prices were collected from local farmers' markets during 2011-12, 2012-13, and 2013-14.

$$
\begin{aligned}
& \text { Maize equivalent yield }\left(\mathrm{kg} \mathrm{ha}^{-1}\right)=\text { Crop yield }\left(\mathrm{kg} \mathrm{ha}^{-1}\right) \\
& \times \text { Crop price }\left(\$ \mathrm{~kg}^{-1}\right) / \text { Maize Price }\left(\$ \mathrm{~kg}^{-1}\right)
\end{aligned}
$$

\section{Economic Analysis}

Economic performance of the systems was assessed using the CIMMYT economic training manual (CIMMYT, 1988), which included step-wise procedures of partial budgeting, dominance, and marginal analyses. The partial budgeting used total variable cost, gross field benefits and net field benefits under each scenario. The variable costs included human labor, bullock drawn plow used for land preparation, and cost of inputs such as seed, fertilizer, and farm yard manure (FYM). The unit of human labor was based on labor day(s) ha ${ }^{-1}$ and was calculated by recording the time required for each agricultural activity and converting them to labor days ( $8 \mathrm{~h}$ being equivalent to 1 labor day). The cost of labor was calculated using the minimum wage rate for the study years as per the Labor Law of the Government of India. Similarly, the time required by the bullock drawn plow to complete the tillage practice was recorded and expressed as day(s) $\mathrm{ha}^{-1}$ ( $8 \mathrm{~h}$ being equivalent to $1 \mathrm{day}$ ). Gross field benefits were calculated by multiplying the field price of maize by the MEY, where field price of maize was estimated by taking the price that farmers receive for the crop when they sell it, and subtracting all the associated costs associated with harvest and sale proportional to the yield. Net benefits were calculated as the difference between gross field benefits and total variable costs. Next, a dominance analysis was carried out by first listing the treatments in order of increasing variable costs. Then, any treatment having net benefits less than or equal to that of a treatment of lower variable costs was considered dominated. In order to have a firm treatment recommendation, a marginal analysis was done using marginal rate of return and a net benefit curve. Marginal rate of return was calculated by marginal net benefit (i.e., change in net benefits) divided by marginal cost (i.e., change in total variable costs), expressed as a percentage. A plot displaying net benefits against total variable cost was created to represent the net benefits curve. It is assumed that farmers will continue to invest as long as the returns to each extra unit invested (measured by the marginal rate of return) are higher than the cost of the extra unit invested (measured by the minimum acceptable rate of return). Minimum acceptable return is the level of additional returns, beyond the cost of capital that will satisfy the farmers that their investment is worthwhile. For the reduced tillage treatment, we used an accepted level of 80\% (CIMMYT, 1988). Finally, a sensitivity analysis was performed to evaluate the stability of recommendations against price fluctuations.

\section{Data Analysis}

After ensuring normality and homogeneity of variance of the data, they were subjected to repeated measures multivariate analysis of variance (MANOVA) and analyzed for significance using appropriate $F$-test (SAS Institute, 2001). Where the F-test were significant, means were compared using Tukey's honest 
significance difference (HSD) test at $P<0.05$. Due to nonsignificant effect of year, pooled data over the three cropping seasons were taken into consideration for analysis of crop yield and system productivity. Economic analysis of crop production though did not include any statistical analysis but was based on the statistical outcome of total system productivity.

\section{RESULTS AND DISCUSSION}

\section{Effect of Conservation Agriculture Production Systems (CAPSs) on Maize and Cowpea Yields}

Maize yields in all treatments and years averaged $4888 \mathrm{~kg} \mathrm{ha}^{-1}$ and did not differ statistically by treatment or year (Figure $\mathbf{3 A}$ ).
This is considerably greater than the national average of $2285 \mathrm{~kg}$ $\mathrm{ha}^{-1}$ (Directorate of Maize Research, India, 2011-12). This might be attributed to favorable rainfall distribution pattern and soil fertility of the site coupled with the use of an improved maize variety and application of recommended agronomic practices. In most cases, results from long term conservation agriculture studies have shown that maize yields in the initial years are not significantly different from conventional practices (Thierfelder et al., 2013). Immediate yield benefits of CA were observed only in some field studies such as in Ngwira et al. (2012) where benefits of conservation agriculture on maize yields were realized in the very first year itself in one of the study sites. There are also numerous other studies regarding the variability of short term yield responses (positive, neutral, or negative yield responses) to conservation agriculture practices (Lal, 1986; Gill

A

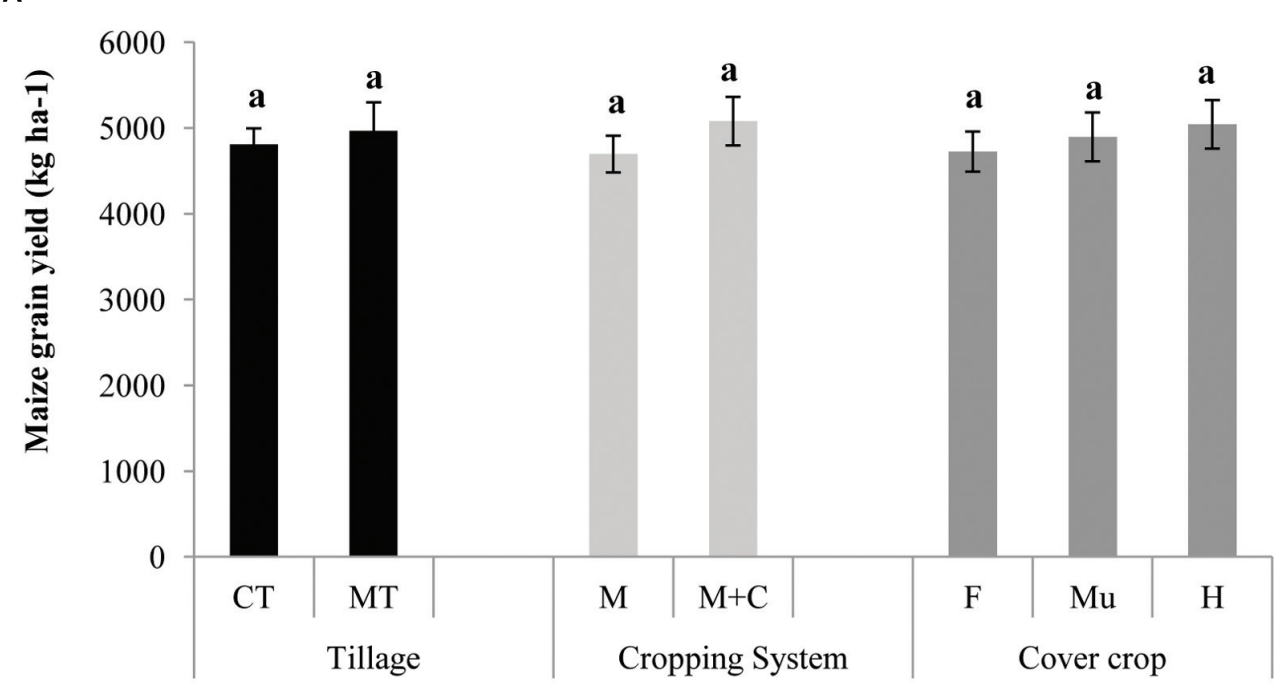

B

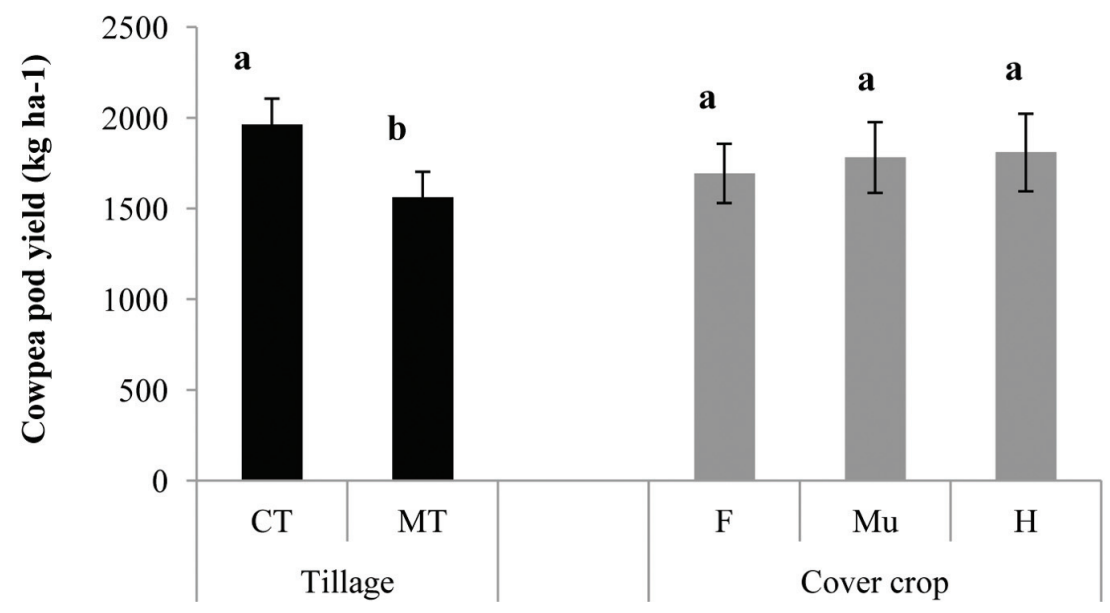

FIGURE 3 | Effect of conservation agriculture production systems (CAPSs) on (A) maize and (B) cowpea yields in kg ha ${ }^{-1}$, averaged over three cropping seasons (2011-2014). Bars represent mean value \pm 1 standard error. Within each CAPS component, means followed by the same letter are not significantly different at $P<0.05$ according to Tukey's HSD test $(n=3)$. CT, conventional tillage; MT, minimum tillage; M, only maize cropping; M+C, maize cowpea intercropping; $\mathrm{F}$, fallow (no cover crop); $\mathrm{Mu}$, mustard residue as cover; $\mathrm{H}$, horsegram residue as cover. 
A

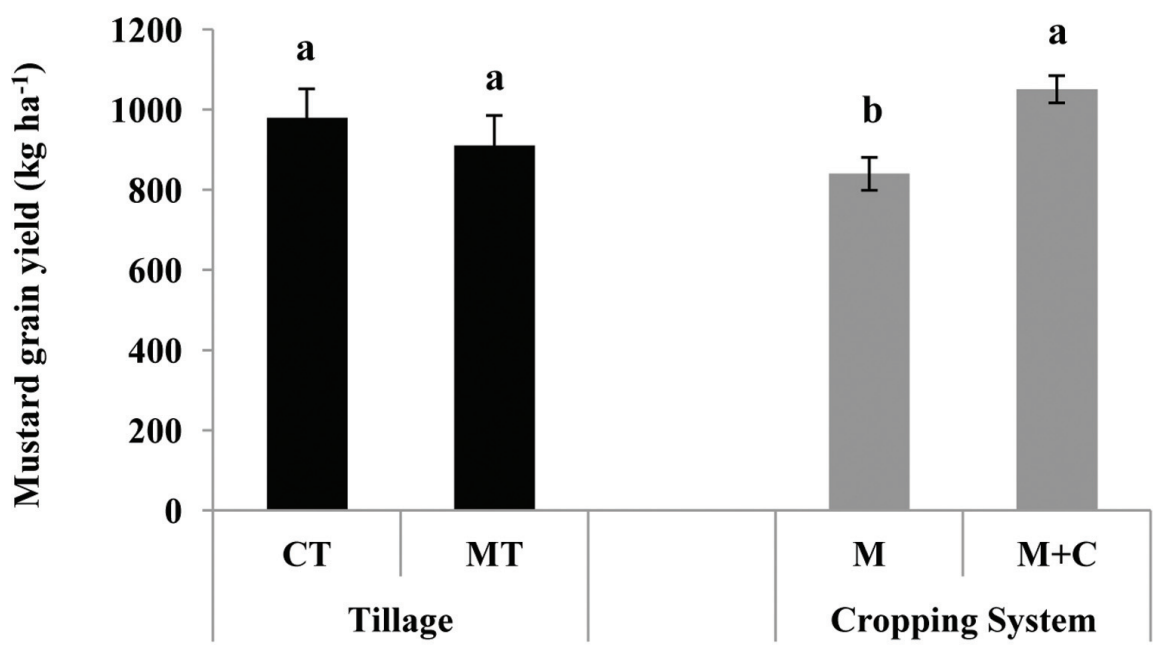

B

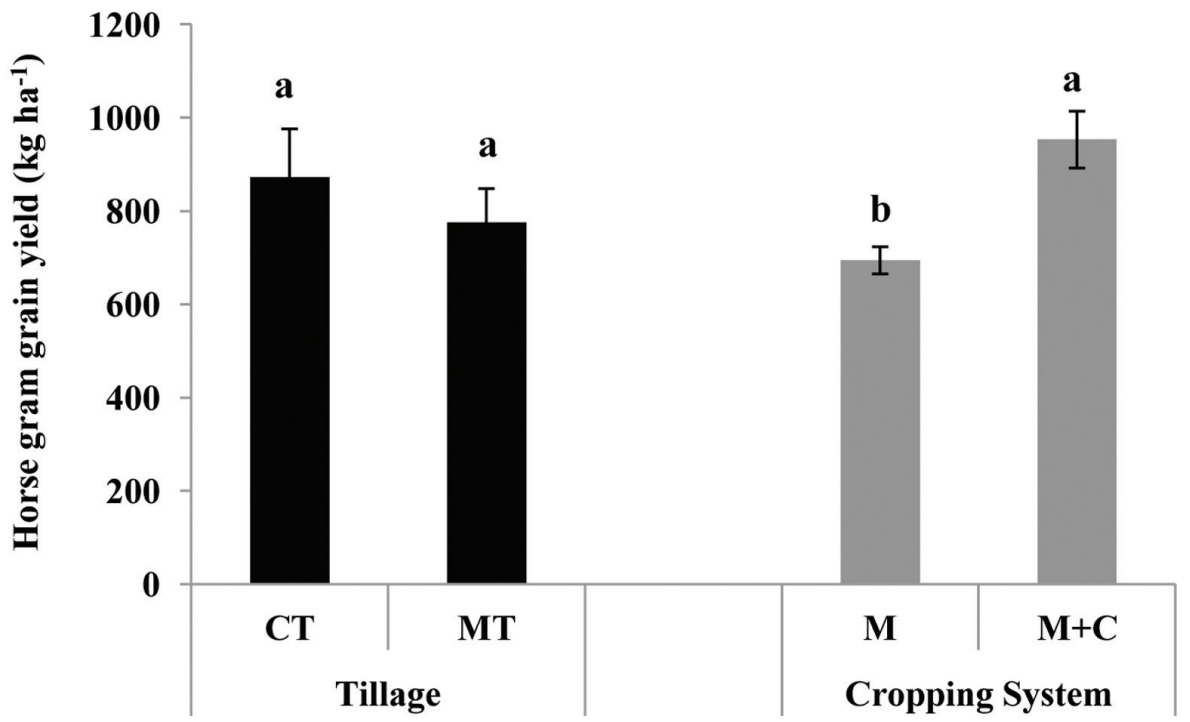

FIGURE 4 | Effect of CAPSs on (A) mustard and (B) horsegram yields in $\mathrm{kg} \mathrm{ha}^{-1}$, averaged over three cropping seasons (2011-2014). Bars represent mean value \pm 1 standard error. Within each CAPS component, means followed by the same letter are not significantly different at $P<0.05$ according to Tukey's HSD test $(n=3)$. CT, conventional tillage; MT, minimum tillage; M, only maize cropping; M+C, maize cowpea intercropping; F, fallow (no cover crop); Mu, mustard residue as cover; $\mathrm{H}$, horsegram residue as cover.

and Aulakh, 1990; Mbagwu, 1990; Mupangwa et al., 2012). In general, conservation agriculture yield benefits took longer to establish a clear upward trend. The reason is generally attributed to the time necessary to build soil fertility and to adapt to the new conservation agriculture system - a phenomenon called "age hardening" for soils transitioning from intensive tillage to minimum or no-tillage (Dexter et al., 1988). Even though shortterm yield effects of conservation agriculture are variable over space and time, yield responses over a longer time period tend to be neutral to positive (Giller et al., 2009; Gilbert, 2012).
Cowpea did not appear to compete with the maize crop, as there was no significant difference in maize yields between maize monocrop and maize-cowpea intercrop (Figure 3B). Past studies have also shown a full range of responses of maize to intercropping, including yield reductions (Adeniyan et al., 2007; Lemlem, 2013), neutral responses (Watiki et al., 1993; Thobatsi, 2009; Ngwira et al., 2012) and yield increases (Nzabi et al., 2000; Mpairwe et al., 2002; Dapaah et al., 2003). In our study, the neutral response might be due to the delayed sowing of cowpea, intended to minimize competition with 
maize during the critical crop establishment stage (Thierfelder et al., 2012). Thus, cowpea yield may be considered as an additional yield in intercropping systems. As there is a good market for the crop in the region, getting a 'bonus' yield from such areas of existing land constraints will not only improve household income but also improves food and nutritional security. Furthermore, such diversification of maize with cowpea can reduce the risk of complete crop failure in times of drought as was reported by Rusinamhodzi et al. (2012). Tillage did have a significant effect on both cowpea pod and stover yield $(P<0.05)$. Yield of cowpea pods and stover were 26 and $30 \%$ greater respectively, in conventional than minimum tillage (Figure 3B). Deeper plowing in conventional tillage might have facilitated better root growth of cowpea and thereby showing increased yield. In the long term, increased production and retention of legume biomass may improve the short-term system performance by controlling runoff and by stimulating macrofauna activity (Mannering and Meyer, 1963; Lal, 1988; Mando et al., 1999). It should also lead to increased water infiltration from the creation of a larger number of root channels (Baudron et al., 2012). Cowpea yields in 2012-13 and 201314 were significantly higher than in 2011-12. An unusually heavy rainfall of around $685 \mathrm{~mm}$ during September might have damaged the cowpea crops leading to lower yield in 2011-12 (Figure 1A).

\section{Effect of Conservation Agriculture Production Systems (CAPSs) on Mustard and Horsegram Yields}

While the cover crop treatments did not affect maize or cowpea yields, there was a significant effect of cropping system on both mustard and horsegram yields (Figures 4A,B). Mustard and horsegram grown in plots after maize+cowpea intercropping had higher grain yields of 25 and 37\%, respectively, as compared to those without intercropping. This might be due to more soil nitrogen through biological nitrogen fixation in intercropped plots.

While cover crops can improve soil quality and thus longterm system productivity, for many smallholders in seasonally dry areas, crop residue is an important source of livestock fodder (Mtambanengwe and Mapfumo, 2005; Giller et al., 2009; Umar et al., 2011; Valbuena et al., 2012). Moreover, fields left fallow during this period are traditionally available for communal grazing (McDowell, 1988; Shepherd, 1992). An advantage of mustard over horsegram is that the mustard stover is generally avoided by livestock, reducing the risk of loss when returned and applied as surface mulch. This infers better acceptability of mustard residue retention over horsegram as communal grazing plays an important role in small holder farming systems.

\section{Effect of Conservation Agriculture Production Systems (CAPS) on Total System Productivity}

Total system productivity over the initial 3 years of crop management was estimated by analyzing the yield contributions of cowpea, mustard, and horse gram toward MEY under different CAPS (Figure 5). Both intercropping and cover cropping significantly increased total system productivity, due not only to the additional yield but also their higher market price, 1.5-2.0 times that of maize. Similarly, intercropping plus cover cropping performed significantly better than intercropping followed by fallow, but there was no difference between cover crops (mustard or horsegram). As there was no effect of tillage, similar system productivity can be achieved with less labor.

N.B: the market price of maize grain $\$ 0.17 \mathrm{~kg}^{-1}$, cowpea pod $\$ 0.28 \mathrm{~kg}^{-1}$, mustard seed $\$ 0.43 \mathrm{~kg}^{-1}$, and horsegram seed

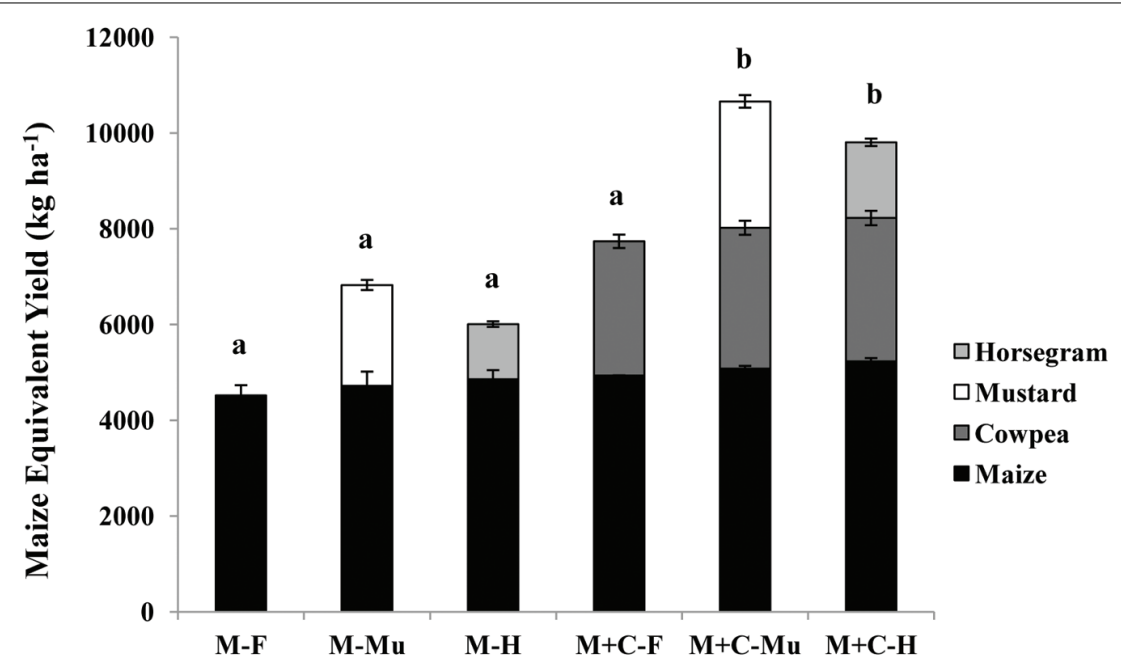

FIGURE 5 | Effect of CAPSs (cropping * cover cropping) on total system productivity in terms of maize equivalent yield (MEY) in kg ha-1, averaged over three cropping seasons (2011-2014). Bars represent mean value \pm 1 standard error. Within each CAPS component, means followed by the same letter are not significantly different at $P<0.05$ according to Tukey's HSD test $(n=3)$. M, only maize cropping; M+C, maize cowpea intercropping; F, fallow (no cover crop); $\mathrm{Mu}$, mustard residue as cover; $\mathrm{H}$, horsegram residue as cover. 


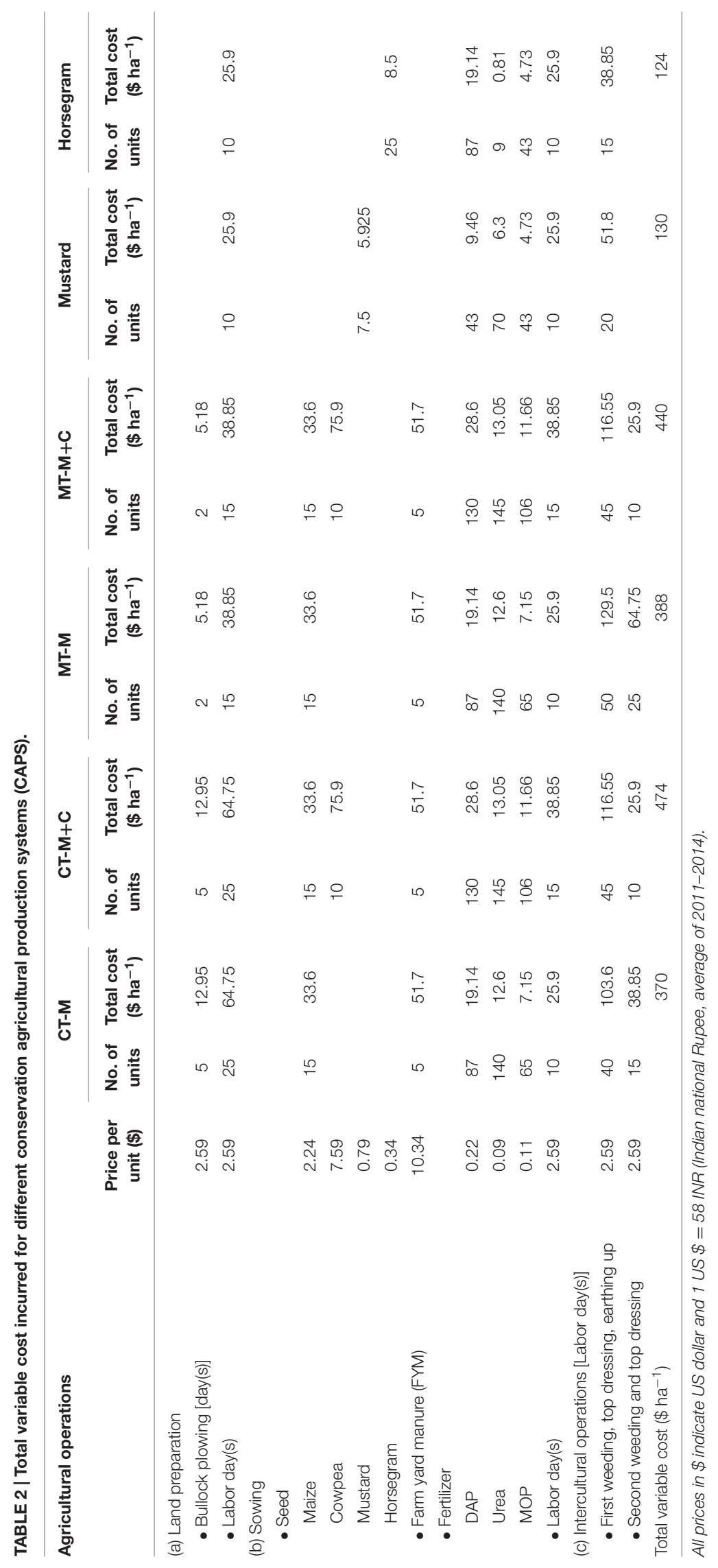


$\$ 0.28 \mathrm{~kg}^{-1}$ [1 US Dollar (USD) $=58$ Indian National Rupee (INR)]; Price of crops was collected from local market survey.

\section{Economic Analysis of Conservation Agriculture Production Systems (CAPSs)}

The economic analysis for all the crops individually and on a system basis was done considering all the variable costs, gross field benefits and net benefits (Tables 2 and 3). The analysis was based on pooled data over 3 years. Conventional tillage with intercropping followed by cultivation of mustard had highest total variable costs of $\$ 604 \mathrm{ha}^{-1}$. This was mainly due to an additional inputs (seeds + fertilizer) and labor for growing the additional crops. The lowest variable costs were under conventional tillage with maize cropping followed by no cover crop $\left(\$ 370 \mathrm{ha}^{-1}\right)$. Minimum tillage overall was only slightly lower in variable cost than conventional tillage $(\sim 2 \%)$. The reduced labor for plowing and land preparation under reduced tillage was largely offset by the increased labor requirement for weeding. This has also been reported in previous studies (Giller et al., 2009; Mazvimavi and Twomlow, 2009). Cowpea intercropping, however, reduced weeding as it formed a closed canopy in the maize inter-row space. This is in agreement with Olsen et al. (2005) who reported that formation of a closed canopy through legume intercropping helps in controlling weeds. Similarly, according to Banik et al. (2006), density and biomass of weeds in diversified cropping systems diminished significantly when compared with single culturing of each component of the diversified system.

Both gross and net field benefits were highest under minimum tillage with intercropping followed by mustard (Table 3 ). The lowest gross and net benefits were under minimum tillage with sole maize and no cover crop. The dominance analysis resulted in four treatments that improved net benefits compared to treatments with lower variable cost: CT-M-F and the three MT-M+C treatments. Marginal analysis of all these selected treatments showed a fivefold increase in marginal benefits by shifting from CT-M-F to MT-M+C-F (Figure 6). Adding mustard as a cover crop had a higher marginal net benefit (228\%) than horsegram (128\%). This was primarily due to the higher economic yield of mustard; the increased cost was almost the same. We observed that such attractive marginal rates of return will help in popularizing conservation agriculture among smallholder farmers as monetary gains act as a prime driver for adoption (Erenstein et al., 2008). Further, higher marginal rates of return will enable the farmers to invest in inputs such as seeds and fertilizer. The sensitivity analysis showed that shifting to intercropping and using mustard as a cover crop both met the recommended minimum rate of return $(80 \%)$, even under an increase in labor costs of 33-40\% (Table 4). The marginal net benefits of horsegram were close to $80 \%$ under these scenarios.

Percentage values along the lines indicate marginal rate of return, which is calculated by marginal net benefit (i.e., change in net benefits) divided by marginal cost (i.e., change in total variable costs), expressed as a percentage.

\section{CONCLUSION}

Agriculture in developing countries primarily focuses on finding a sustainable agricultural technology that meets the demands of smallholder farmers while maintaining or improving soil fertility. Though there is no universal strategy to end challenges to food

TABLE 3 | Partial budget and dominance analysis of conservation agriculture production systems (CAPSs).

\begin{tabular}{|c|c|c|c|c|c|c|c|}
\hline Tillage & $\begin{array}{l}\text { Cropping } \\
\text { system }\end{array}$ & Residue cover & $\begin{array}{c}{ }^{\text {a Average }} \\
\text { yield }\left(\mathrm{kg} \mathrm{ha}^{-1}\right)\end{array}$ & $\begin{array}{c}{ }^{\mathrm{b}} \text { Adjusted } \\
\text { yield }\left(\mathrm{kg} \mathrm{ha}^{-1}\right)\end{array}$ & $\begin{array}{c}{ }^{\mathrm{c}} \text { Gross field } \\
\text { benefits }\left(\$ \mathrm{ha}^{-1}\right)\end{array}$ & $\begin{array}{l}{ }^{\mathrm{d}} \text { Total variable } \\
\text { costs }\left(\$ \mathrm{ha}^{-1}\right)\end{array}$ & $\begin{array}{c}\text { e Net benefits } \\
\left(\$ \text { ha }^{-1}\right)\end{array}$ \\
\hline \multirow[t]{6}{*}{ Coventional Tillage } & Maize & Fallow & 4777 & 4538 & 681 & 370 & 311 \\
\hline & & Mustard & 7186 & 6827 & 1024 & 500 & $524^{\dagger}$ \\
\hline & & Horsegram & 6237 & 5925 & 889 & 494 & 395 \\
\hline & Maize+cowpea & Fallow & 7735 & 7348 & 1102 & 474 & 628 \\
\hline & & Mustard & 10585 & 10056 & 1508 & 604 & 904 \\
\hline & & Horsegram & 9882 & 9388 & 1408 & 598 & 810 \\
\hline \multirow[t]{6}{*}{ Minimum Tillage } & Maize & Fallow & 4260 & 4047 & 607 & 388 & 219 \\
\hline & & Mustard & 6461 & 6138 & 921 & 518 & 403 \\
\hline & & Horsegram & 5776 & 5487 & 823 & 512 & 311 \\
\hline & Maize+cowpea & Fallow & 7739 & 7352 & 1103 & 440 & 663 \\
\hline & & Mustard & 10731 & 10195 & 1529 & 570 & 959 \\
\hline & & Horsegram & 9726 & 9239 & 1386 & 564 & 822 \\
\hline
\end{tabular}

aAverage yield is pooled data of total system productivity in terms of maize equivalent yield over the years.

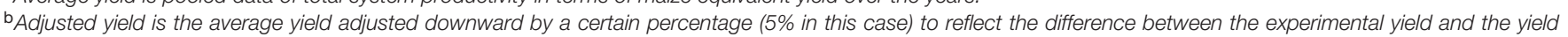

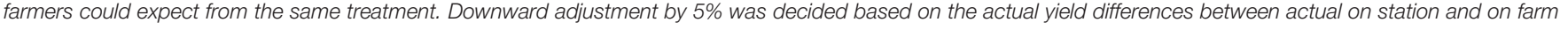
study results.

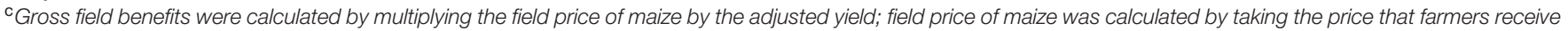
for the crop when they sell it, and subtracting all the associated costs associated with harvest, and sale proportional to the yield.

dTotal variable costs indicate the sum of all the costs that vary for a particular treatment.

eNet benefits are calculated by subtracting gross field benefits from total variable costs.

${ }^{\dagger}$ Net benefits in italics indicate a treatment that is dominated, i.e., the net benefits are less than or equal to that of a treatment with lower variable costs. 

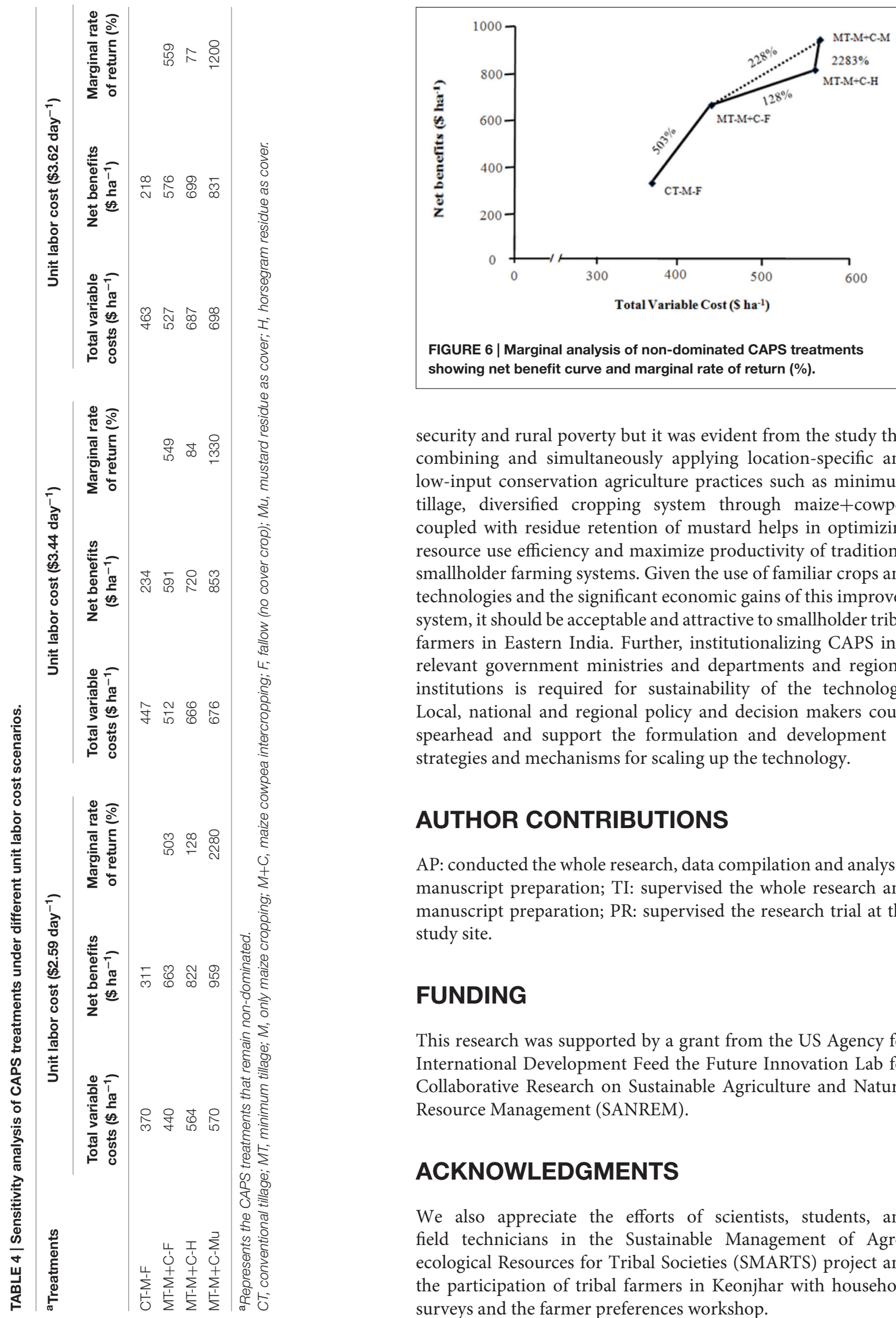

FIGURE 6 | Marginal analysis of non-dominated CAPS treatments showing net benefit curve and marginal rate of return (\%).

security and rural poverty but it was evident from the study that combining and simultaneously applying location-specific and low-input conservation agriculture practices such as minimum tillage, diversified cropping system through maize+cowpea coupled with residue retention of mustard helps in optimizing resource use efficiency and maximize productivity of traditional smallholder farming systems. Given the use of familiar crops and technologies and the significant economic gains of this improved system, it should be acceptable and attractive to smallholder tribal farmers in Eastern India. Further, institutionalizing CAPS into relevant government ministries and departments and regional institutions is required for sustainability of the technology. Local, national and regional policy and decision makers could spearhead and support the formulation and development of strategies and mechanisms for scaling up the technology.

\section{AUTHOR CONTRIBUTIONS}

AP: conducted the whole research, data compilation and analysis, manuscript preparation; TI: supervised the whole research and manuscript preparation; PR: supervised the research trial at the study site.

\section{FUNDING}

This research was supported by a grant from the US Agency for International Development Feed the Future Innovation Lab for Collaborative Research on Sustainable Agriculture and Natural Resource Management (SANREM).

\section{ACKNOWLEDGMENTS}

We also appreciate the efforts of scientists, students, and field technicians in the Sustainable Management of Agroecological Resources for Tribal Societies (SMARTS) project and the participation of tribal farmers in Keonjhar with household surveys and the farmer preferences workshop. 


\section{REFERENCES}

Adeniyan, O. N., Akande, S. R., Balogun, M. O., and Saka, J. O. (2007). Evaluation of crop yield of African Yam bean, cow pea and maize under intercropping systems. Am. Eur. J. of Agric. Environ. Sci. 2, 99-102.

Banik, P., Midya, A., Sarkar, B. K., and Ghose, S. S. (2006). Wheat and chickpea intercropping systems in an additive series experiment advantages and weed smothering. Eur. J. Agron. 24, 325-332. doi: 10.1016/j.eja.2005. 10.010

Baudron, F., Tittonell, P., Corbeels, M., Letourmy, P., and Giller, K. E. (2012). Comparing performance of conservation agriculture and current smallholder farming practices in semi-arid Zimbabwe. Field Crops Res. 132, 117-128. doi: 10.1016/j.fcr.2011.09.008

CIMMYT (1988). From Agronomic Data to Farmer Recommendations: An Economics Training manual. Completely Revised Edition. Annual Report 2003-2004, All India Co-ordinated Research Project for Dry land Agriculture. Hyderabad: Central Research Institute for Dry land Agriculture, 291-301.

Dapaah, H. K., Asafu-Agyei, J. N., Ennin, S. A., and Yamoah, C. Y. (2003). Yield stability of cassava, maize, soybean and cowpea intercrops. J. Agric. Sci. 140, 73-82. doi: 10.1017/S0021859602002770

Dexter, A. R., Horn, R., and Kemper, W. D. (1988). Two mechanisms for age-hardening of soil. Eur. J. Soil Sci. 39, 163-175. doi: 10.1111/j.13652389.1988.tb01203.x

Erenstein, O., Sayer, K., Wall, P., Dixon, J., and Hellin, J. (2008). “Adapting no-tillage agriculture to the smallholder maize and wheat farmers in the tropics and sub-tropics," in No-Till Farming Systems, eds T. Goddard, M. A. Zoebisch, Y. T. Gan, W. Ellis, A. Watson, and S. Sombatpanit (Bangkok: World Association of Soil and Water Conservation), 253-277.

Gilbert, N. (2012). Dirt poor: the key to tackling hunger in Africa is enriching its soil. The big debate is about how to do it. Nature 483, 525-527.

Gill, K. S., and Aulakh, B. S. (1990). Wheat yield and soil bulk-density response to some tillage systems on an Oxisol. Soil Till. Res. 18, 37-45. doi: 10.1016/01671987(90)90091-Q

Giller, K. E., Witter, E., Corbeels, M., and Tittonell, P. (2009). Conservation agriculture and smallholder farming in Africa: the heretics' view. Field Crops Res. 114, 23-34. doi: 10.1016/j.fcr.2009.06.017

Idol, T. (2015). "A brief history of conservation agriculture," in Conservation Agriculture in Subsistence Farming: Case Studies from South Asia and Beyond, eds C. Chan and J. Fantle-Lepczyk (Wallingford: CABI), $1-21$.

Lai, C., Chan, C., Halbrendt, J., Shariq, L., Roul, P., Idol, T., et al. (2012). Comparative economic and gender, labor analysis of conservation agriculture practices in tribal villages in India. Int. Food Agribusiness Manage. Rev. 15, 73-86.

Lal, R. (1986). Soil surface management in the tropics for intensive land use and high and sustained production. Adv. Soil Sci. 5, 1-109. doi: 10.1007/978-1-46138660-5_1

Lal, R. (1988). Effects of macrofauna on soil properties in tropical ecosystems. Agric. Ecosyst. Environ. 24, 101-116. doi: 10.1016/0167-8809(88) 90059-X

Lemlem, A. (2013). The effect of intercropping maize with cowpea and lablab on crop yield. Herald J. Agric. Food Sci. Res. 2, 156-170.

Mando, A., Brussard, L., and Stroosnijder, L. (1999). Termite- and mulch-mediated rehabilitation of vegetation on crusted soil in West Africa. Restoration Ecol. 7, 33-41. doi: 10.1046/j.1526-100X.1999.07104.x

Mannering, J. V., and Meyer, L. D. (1963). The effects of various rates of surface mulch on infiltration and erosion. Soil Sci. Soc. Am. J. 27, 84-86. doi: 10.2136/sssaj1963.03615995002700010029x

Mazvimavi, K., and Twomlow, S. (2009). Socioeconomic and institutional factors influencing adoption of conservation agriculture by vulnerable households in Zimbabwe. Agric. Syst. 101, 20-29. doi: 10.1016/j.agsy.2009. 02.002
Mbagwu, J. (1990). Mulch and tillage effects on water transmission characteristics of an Ultisol and maize grain yield in SE Nigeria. Pedologie 40, 155-168.

McDowell, R. E. (1988). "Importance of crop residues for feeding livestock in smallholder farming systems," in Proceedings of a Workshop Held at International Livestock Centre for Africa: Plant Breeding and the Nutritive Value of Crop Residues, eds J. D. Reed, B. S. Capper, and P. J. H. Neate (Addis Ababa: International Livestock Centre for Africa), 3-27

Mpairwe, D. R., Sabiiti, E. N., Ummuna, N. N., Tegegne, A., and Osuji, P. (2002). Effect of intercropping cereal crops with forage legumes and source of nutrients on cereal grain yield and fodder dry matter yields. Afr. Crop Sci. J. 10, 81-97.

Mtambanengwe, F., and Mapfumo, P. (2005). Organic matter management as an underlying cause for soil fertility gradients on smallholder farms in Zimbabwe. Nutr. Cycl. Agroecosyst. 73, 227-243. doi: 10.1007/s10705-0052652-x

Mupangwa, W., Twomlow, S., and Walker, S. (2012). Reduced tillage, mulching and rotational effects on maize (Zea mays L.), cowpea (Vigna unguiculata (Walp) L.) and sorghum (Sorghum bicolor L. (Moench)) yields under semiarid conditions. Field Crops Res. 132, 139-148. doi: 10.1016/j.fcr.2012. 02.020

Ngwira, A. R., Aune, J. B., and Mkwinda, S. (2012). On-farm evaluation of yield and economic benefit of short term maize legume intercropping systems under conservation agriculture in Malawi. Field Crops Res. 132, 149-157. doi: 10.1016/j.fcr.2011.12.014

Nzabi, A. W., Makini, F., Onyango, M., Kidula, N., Muyonga, C. K., and Miruka, M. (2000). "Effect of intercropping legume with maize on soil fertility and maize yield," in Proceedings of the 2nd Scientific Conference of the Soil Management and Legume Research Network Projects, Mombasa, 193-197.

Olsen, J., Kristensen, L., Weiner, J., and Griepentrog, H. W. (2005). Increased density and spatial uniformity increase weed suppression by spring wheat. Weed Res. 45, 316-321. doi: 10.1111/j.1365-3180.2005. 00456.x

Pradhan, A., Idol, T., Roul, P. K., Mishra, K. N., Chan, C., Halbrendt, J., et al. (2015). "Effect of tillage, intercropping and residue cover on crop productivity, profitability and soil fertility under tribal farming situations of India," in Conservation Agriculture in Subsistence Farming: Case Studies from South Asia and Beyond, eds C. Chan and J. Fantle-Lepczyk (Wallingford: CABI), 77-94.

Roul, P. K., Pradhan, A., Ray, P., Mishra, K. N., Dash, S. N., and Chan, C. (2015). "Influence of maize-based Conservation Agricultural Production Systems (CAPS) on crop yield, profit and soil fertility in rainfed uplands of Odisha, India," in Conservation Agriculture in Subsistence Farming: Case Studies from South Asia and Beyond, eds C. Chan and J. Fantle-Lepczyk (Wallingford: CABI), 95-108.

Rusinamhodzi, L., Corbeels, M., Nyamangara, J., and Giller, K. E. (2012). Maize-grain legume intercropping is an attractive option for ecological intensification that reduces climatic risk for smallholder farmers in central Mozambique. Field crops Res. 136, 12-22. doi: 10.1016/j.fcr.2012. 07.014

SAS Institute (2001). SAS/STAT User's Guide, Version 8.1. Cary, NC: SAS Institute, 1030.

Shepherd, G. (1992). Managing Africa's Tropical Dry Forests: a Review of Indigenous Methods. London: Overseas Development Institute.

Thierfelder, C., Cheesman, S., and Rusinamhodzi, L. (2012). A comparative analysis of conservation agriculture systems: benefits and challenges of rotations and intercropping in Zimbabwe. Field Crops Res. 137, 237-250. doi: 10.1016/j.fcr.2012.08.017

Thierfelder, C., Mwila, M., and Rusinamhodzi, L. (2013). Conservation agriculture in eastern and southern provinces of Zambia: long-term effects on soil quality and maize productivity. Soil Till. Res. 126, 246-258. doi: 10.1016/j.still.2012.09.002

Thobatsi, T. (2009). Growth and Yield Responses of Maize (Zea mays L.) and Cowpea (Vigna unguiculata L.) in an Intercropping System. Masters Dissertation Submitted to Deparment. of Plant Production and Soil Science. Pretoria: University of Pretoria. 
Umar, B. B., Aune, J. B., Johnsen, F. H., and Lungu, O. I. (2011). Options for improving smallholder conservation agriculture in Zambia. J. Agric. Sci. 3, 50-62.

Valbuena, D., Erenstein, O., Homann-Kee Tui, S., Abdoulaye, T., Claessens, L., Duncan, A. J., et al. (2012). Conservation agriculture in mixed crop-livestock systems: scoping crop residue trade-offs in Sub-Saharan Africa and South Asia. Field Crops Res. 132, 175-184. doi: 10.1016/j.fcr.2012.02.022

Watiki, J. M., Fukai, S., Banda, J. A., and Keating, B. A. (1993). Radiation interception and growth of maize/cowpea intercrop as affected by maize plant density and cowpea cultivar. Field Crops Res. 35, 123-133. doi: 10.1016/03784290(93)90145-D
Conflict of Interest Statement: The authors declare that the research was conducted in the absence of any commercial or financial relationships that could be construed as a potential conflict of interest.

Copyright (c) 2016 Pradhan, Idol and Roul. This is an open-access article distributed under the terms of the Creative Commons Attribution License (CC BY). The use, distribution or reproduction in other forums is permitted, provided the original author(s) or licensor are credited and that the original publication in this journal is cited, in accordance with accepted academic practice. No use, distribution or reproduction is permitted which does not comply with these terms. 